\title{
Influence of specific obsessive-compulsive symptom dimensions on strategic planning in patients with obsessive-compulsive disorder
}

\section{Avaliação de planejamento estratégico em pacientes com transtorno obsessivo-compulsivo de acordo com as dimensóes de sintomas obsessivo-compulsivos}

\author{
Paula Sanders Pereira Pinto, ${ }^{1,2}$ Sandro lego, ${ }^{1}$ Samantha Nunes, ${ }^{1}$ Hemanny Menezes, ${ }^{1}$ Rosana Sávio Mastrorosa, ${ }^{3}$ \\ Irismar Reis de Oliveira, ${ }^{1}$ Maria Conceição do Rosário ${ }^{1,3}$
${ }^{1}$ Consórcio Brasileiro de Pesquisa em TOC (CTOC), Serviço de TOC do Ambulatório Magalhães Neto (SERTOC), Hospital das Clínicas, Universidade Federal da Bahia (UFBA), Salvador, BA, Brazil
2 Universidade de Salvador (UNIFACS), Salvador, BA, Brazil São Paulo, SP, Brazil \\ 3 Unidade de Psiquiatria da Infância e Adolescência (UPIA), Departamento de Psiquiatria, Universidade Federal de São Paulo (UNIFESP),
}

\begin{abstract}
This study was conducted as part of a larger study, entitled "Características clínicas dos portadores de transtorno obsessivo-compulsivo, transtorno de tiques e síndrome de Tourette do Ambulatório Transtornos do Espectro Obsessivo-Compulsivo (SERTOC) do Serviço de Psiquiatria do Hospital Universitário Professor Edgar Santos" ("Clinical characteristics of individuals with obsessive-compulsive disorder, tic disorder, and Tourette syndrome at the Obsessive-Compulsive Spectrum Disorders Outpatient Clinic of the Psychiatry Department of the Professor Edgar Santos University Hospital"), coordinated by Dr. Irismar Reis de Oliveira. The study design was approved by the Research Ethics Committee of the Prof. Edgar Santos (PARECER/ RESOLUÇÃO 127/2007) University Hospital, Universidade Federal da Bahia (UFBA).
\end{abstract}

\begin{abstract}
Objective: This study investigates obsessive-compulsive disorder patients in terms of strategic planning and its association with specific obsessivecompulsive symptom dimensions. Method: We evaluated 32 obsessivecompulsive disorder patients. Strategic planning was assessed by the ReyOsterrieth Complex Figure Test, and the obsessive-compulsive dimensions were assessed by the Dimensional Yale-Brown Obsessive-Compulsive Scale. In the statistical analyses, the level of significance was set at $5 \%$. We employed linear regression, including age, intelligence quotient, number of comorbidities, the Yale-Brown Obsessive-Compulsive Scale score, and the Dimensional YaleBrown Obsessive-Compulsive Scale. Results: The Dimensional Yale-Brown Obsessive-Compulsive Scale "worst-ever" score correlated significantly with the planning score on the copy portion of the Rey-Osterrieth Complex Figure Test $(\mathrm{r}=0.4, \mathrm{p}=0.04)$ and was the only variable to show a significant association after linear regression $(\beta=0.55, \mathrm{t}=2.1, \mathrm{p}=0.04)$. Compulsive hoarding correlated positively with strategic planning $(r=0.44, p=0.03)$. None of the remaining symptom dimensions presented any significant correlations with strategic planning. Conclusion: We found the severity of obsessive-compulsive symptoms to be associated with strategic planning. In addition, there was a significant positive association between the planning score on the copy portion of the Rey-Osterrieth Complex Figure Test copy score and the hoarding dimension score on the Dimensional Yale-Brown Obsessive-Compulsive Scale. Our results underscore the idea that obsessive-compulsive disorder is a heterogeneous disorder and suggest that the hoarding dimension has a specific neuropsychological profile. Therefore, it is important to assess the peculiarities of each obsessive-compulsive symptom dimension.
\end{abstract}

Descriptors: Obsessive-compulsive disorder; Evaluation; Signs and symptoms; Executive function; Strategic planning

\section{Resumo}

Objetivo: Este estudo investiga o planejamento estratégico em pacientes com transtorno obsessivo-compulsivo e sua possivel associação com dimensōes de sintomas obsessivo-compulsivos. Método: Foram avaliados 32 pacientes com transtorno obsessivo-compulsivo. O planejamento estratégico foi avaliado pelo Teste da Figura Complexa de Rey. Presença e gravidade de sintomas obsessivocompulsivos foram avaliadas pela Escala Dimensional para Sintomas ObsessivoCompulsivos e a Yale-Brown Obsessive-Compulsive Scale. Análises estatísticas foram realizadas utilizando nivel de significância de 5\%. Resultados: Escores globais da Escala Dimensional para Sintomas Obsessivo-Compulsivos na pior fase apresentaram correlação significativa com os escores de cópia do Teste da Figura Complexa de Rey-Osterrieth $(r=0,4, p=0,04)$, além de manter significância na análise de regressão, incluindo idade, quociente de inteligência, número de comorbidades e escores no Yale-Brown Obsessive-Compulsive Scale e Escala Dimensional para Sintomas Obsessivo-Compulsivos $\beta=0,55, t=2,1$, $p=0,04)$. A dimensão colecionismo teve uma correlação significativa com o escore de planejamento estratégico $(r=0,44, p=0,03)$. As outras dimensões de sintomas obsessivo-compulsivos não apresentaram correlaçôes significativas com os escores de planejamento estratégico. Conclusão: A gravidade dos sintomas obsessivo-compulsivos e a dimensão colecionismo apresentaram associaçôes significativas com escores de planejamento estratégico na cópia do Teste da Figura Complexa de Rey. Os achados reforçam a ideia de que o transtorno obsessivo-compulsivo é um transtorno heterogêneo, e de que é importante avaliar as especificidades de cada dimensão de sintomas obsessivo-compulsivos, além de sugerir que a dimensão colecionismo apresenta características neuropsicológicas distintas.

Descritores: Transtorno obsessivo-compulsivo; Avaliação; Sinais e sintomas; Função executiva; Planejamento estratégico 


\section{Introduction}

Obsessive-compulsive disorder (OCD) is characterized by the presence of intrusive and recurrent obsessions or compulsions, the maintenance of which requires at least one hour a day or which otherwise have a significant effect on the life of the patient. ${ }^{1}$

It has been proposed that OCD affects the basal ganglia and frontostriatal structures, with consequent impairment of executive functions. ${ }^{2,3}$ The term "executive functions" is quite broad and encompasses various psychological functions. Executive functions that have been associated with OCD include mental flexibility, nonverbal memory, verbal memory, visuospatial skills, psychomotor speed, and strategic planning. ${ }^{3,4}$

It has been demonstrated that strategic planning, defined as "the ability to organize information into its most simple (or semantically related) components, making it easier to learn and memorize", is impaired in patients with OCD. ${ }^{2,3}$ Dysfunction in strategic planning can lead to an excessive concern with details, lack of semantic associations, difficulty in modifying the cognitive stage, and impairment in nonverbal memory. ${ }^{2}$ Mataix-Cols et al. reported that OCD patients used unproductive organizational strategies during the copy portion of the Rey-Osterrieth Complex Figure Test (ROCFT), thereby corroborating the findings of Oliveira. ${ }^{5,6}$

Planning deficits have also been linked to frontal lobe dysfunction. ${ }^{2}$ Studies conducted in attempts to explain the functioning of the brain have shown increased metabolic rates in the orbitofrontal cortex of OCD patients during tests involving the use of organizational strategies. ${ }^{7}$ Choi et al. found a correlation between the volume of gray matter in the left anterior orbitofrontal cortex and the final score on the copy portion of the ROCFT in patients with $\mathrm{OCD}$, indicating that executive functions are related to the functioning of the frontal lobes. ${ }^{8}$

In a study involving 68 subjects (35 OCD patients without depression and 33 healthy controls), Penadés et al. found a significant correlation between strategic planning and the severity of obsessive-compulsive (OC) symptoms, greater OC symptom severity translating to worse strategic planning. ${ }^{3}$ One of the shortcomings of their study was that they did not investigate the possible effects of OCD heterogeneity. Although OCD has been described as a unitary nosological disorder, many studies have demonstrated that it is in fact clinically and etiologically heterogeneous. Therefore, a variety of approaches have been employed in attempts to identify OCD patient subgroups that are more homogeneous. ${ }^{9}$ Some of the most fruitful have evaluated the age at onset of the OC symptoms $s^{10,11}$ and the presence of comorbidities, especially tic disorders. ${ }^{9,12}$ Despite having certain advantages, these attempts have had limited success in determining whether the subtypes identified correlate with specific biological markers, genetic factors, or treatment responses. This can be explained, in part, by the fact that pure subtypes are rare, and that the recruitment of sufficient sample sizes of each subtype is difficult and highly impractical.

Recent studies have proposed the use of a dimensional approach to OCD, ${ }^{13,14}$ which regards OC symptom dimensions as a continuum, ranging from normal worries or behaviors to extremely severe symptoms. Within the context of this proposal, OC symptom dimensions are not exclusively bound to their descriptions in the diagnostic manuals currently in use. ${ }^{13,14}$ There have been a number of studies employing factorial analysis, collectively involving more than 4,000 patients with OCD in various countries. ${ }^{15}$ Those studies have consistently identified between three and five OC symptom dimensions or factors as being the most prominent: aggressive/sexual/religious obsessions and related compulsions; symmetry/ordering/arranging obsessions and compulsions; contamination obsessions and cleaning compulsions; and hoarding obsessions and compulsions. ${ }^{13}$ It should be noted that these OC symptom dimensions have been shown to be, variously, temporally stable; ${ }^{16,17}$ similar at different ages; ${ }^{18,19}$ useful in the identification of genetic and neurobiological factors; ${ }^{14,20}$ and helpful in determining treatment strategies. ${ }^{21-23}$

Despite the great potential for a better understanding of the etiology of OCD, there have been very few studies investigating the neuropsychological performance of patients by OC symptom dimension. In the present study, we sought to identify associations between strategic planning and specific OC symptom dimensions. Our hypothesis was that each OC symptom dimension would correlate differently with the strategic planning scores.

\section{Method}

\section{Sample}

This was a cross-sectional study. Data were collected at the Obsessive-compulsive Spectrum Disorders Outpatient Clinic of the Magalhães Neto University Hospital of the Federal University of Bahia, between November of 2007 and December of 2008. The Clinic is one of seven facilities affiliated with the Consórcio Brasileiro de Pesquisa em Transtornos do Espectro Obsessivo-Compulsivo (CTOC, Brazilian Research Consortium on Obsessive-Compulsive Spectrum Disorders). The CTOC has the objective of investigating the characteristics of OCD patients and their families, spanning all areas of OCD research. ${ }^{24}$

This study was conducted in accordance with the guidelines on research involving human subjects established in the Declaration of Helsinki (1996) and in Brazilian National Health Council Resolution 196/96. The project was approved by the Research Ethics Committee of the Prof. Edgar Santos Hospital on Universidade Federal da Bahia (Advice 127/2007).

After having been given a thorough explanation of the study objectives and the assurance that their decision to participate would not interfere with their access to treatment, all participants gave written informed consent.

A total of 37 subjects, ranging from 18 to 65 years of age, were invited to participate in the study. All had a confirmed diagnosis of OCD according to the DSM-IV criteria. ${ }^{1}$ Five subjects did not conclude the assessment. Therefore, the final sample was composed of 32 patients. 


\section{Instruments}

The following instruments were applied: the structured clinical interview for DSM-IV Axis I disorders - patient edition (SCIDI/P); ${ }^{25}$ the Dimensional Yale-Brown Obsessive-Compulsive Scale (DY-BOCS); $;{ }^{26}$ the Yale Brown Obsessive-Compulsive Scale (Y-BOCS); ${ }^{27}$ the Beck Depression Inventory (BDI); ${ }^{28,29}$ and the Beck Anxiety Inventory (BAI) ${ }^{28-30}$ Intelligence was assessed by the Wechsler Abbreviated Scale of Intelligence (WASI), ${ }^{31}$ and strategic planning was assessed by the planning score on the ROCFT. ${ }^{6}$ Some of these instruments were described in greater detail in a previous ${ }^{24}$ report by the CTOC..$^{24}$

\section{Evaluation of OC symptom dimensions}

\section{1) DY-BOCS}

The DY-BOCS, which comprises six dimensions, assesses the severity of OC symptoms. ${ }^{26}$ It has been shown to have excellent psychometric properties. ${ }^{26}$ The instrument consists of 88 examples of OC symptoms, ${ }^{26}$ accompanied by questions that assess their severity. The severity scores, divided into current and "worst-ever" scores, are based on how much patient time is lost in dealing with OC symptoms, as well as on the level of patient distress caused by those symptoms and the degree to which they impair patient quality of life. Severity scores range from 0 to 15 for each dimension. The impairment caused by the OC symptoms is also measured on a scale of 0 of 15 . The total score for each dimension therefore ranges from 0 to 30 . Another feature of this scale is that avoidance behaviors, recurrent thoughts, and repetitive rituals are investigated within each dimension, allowing an accurate assessment of the severity of each symptom.

\section{Neuropsychological evaluation}

1) ROCFT 6

The ROCFT is an instrument designed to investigate perceptual organization and visual memory. The English-language version of the test ${ }^{6}$ has been duly translated to Portuguese, ${ }^{6}$ and the Portuguese-language version has been adapted and validated for use in Brazil. ${ }^{32}$

The ROCFT presents a geometric figure in which 18 items are assessed. The subject is asked to copy the figure and subsequently (after $3 \mathrm{~min}$ ) asked to recall and re-create it. ${ }^{6}$ In each of the two portions (copy and immediate recall), the subject receives a score for planning. The planning scores ranges from 0 (worst) to 6 (best) and is considered the best measure of strategic planning. $17,19,20$ The rater then attempts to identify the five basic elements of the figure (rectangle base, two diagonals, center vertical line, center horizontal line and the triangle vertex on the right). The rectangle base is worth up to 2 points, and the other elements are worth 1 point each. The order in which the subject constructs the figure does not affect the score. ${ }^{4}$

Although planning can be assessed on the basis of the scores on both portions of the test (copy and immediate recall), studies have suggested that the planning score obtained for the copy portion of the test is the best measure of strategic planning. ${ }^{3-5}$

\section{2) WASI ${ }^{31}$}

The WASI consists of four subtests: Vocabulary; Similarities; Block Designs; and Matrix Reasoning. ${ }^{31}$ The scale provides the rates of performance, verbal intelligence quotient (IQ), and full-scale IQ with scores that range from 50 to 160 . Since the Brazilian normative data have not yet been published, the American norms were used.

\section{Statistical analysis}

The software used for statistical analysis and data storage was the Statistical Package for the Social Sciences, version 15.0 (SPSS Inc., Chicago, IL, USA). ${ }^{33}$ Bivariate correlations were evaluated in all tests, and the level of statistical significance was set at $5 \%$ $(\alpha=0.05)$.

Descriptive analysis was performed for data related to prevalence, percentage, mean, median, standard deviation, and range, in order to characterize the variables that make up the profile of the selected sample: age; sex; level of education; manual dexterity; number of psychiatric comorbidities; depression; symptoms of anxiety; and use of medication.

The bivariate correlations were obtained through Pearson's correlation coefficient. Each OC symptom dimension was tested separately in ${ }^{4}$ order to identify associations with strategic planning scores. There is evidence that strategic planning scores are influenced by age, IQ, level of education, and the presence of comorbid disorders, as well as by the severity of depressive and anxiety symptoms (BDI and BAI scores). ${ }^{4}$ Therefore, these variables were also included in the analyses. Before applying Pearson's correlation test, we evaluated the linearity between variables in the dispersion diagrams and we used the Kolmogorov-Smirnov test to determine whether the data were normally distributed.

Certain clinical features, such as WASI full-scale IQ, age, number of comorbid diagnoses, and OC symptom severity have been associated with strategic planning scores., ${ }^{2,3}$ Therefore, we performed linear regression analysis in order to determine which of these clinical features (considered independent variables) correlated with the planning score on the copy portion of the ROCFT (considered a dependent variable).

\section{Results}

In our study sample, females predominated (accounting for $56.3 \%)$, most (68.8\%) of the subjects were single, and the majority $(81.3 \%)$ were right-handed. The mean age was $34.3 \pm 12.6$ years, and the mean IQ was $95.1 \pm 14.6$ (Table 1).

Twenty-eight subjects $(81.3 \%)$ had comorbidities, the mean number of comorbid diagnoses being $2.7 \pm 2.0$, and $87.5 \%$ were taking medication. The most common comorbidities were depression (in 56.3\%) and anxiety disorders (in 62.5\%). The mean age of onset of OC symptoms was $16.3 \pm 9.5$ years (Table 1 ).

As can be seen in Table 2, the highest mean DY-BOCS scores were observed for the symmetry dimension (worst-ever, $9.7 \pm$ 4.1 ; current, $7.2 \pm 4.1$ ). Symmetry was also the most common symptom (worst-ever, $\mathrm{n}=28$; current, $\mathrm{n}=30$ ).

The mean planning scores on the copy and immediate recall portions of the ROCFT were $5.3 \pm 1.3$ and $4.1 \pm 1.9$, respectively (Table 3). 
Table 1 - Demographic and clinical characteristics of 32 patients with OCD

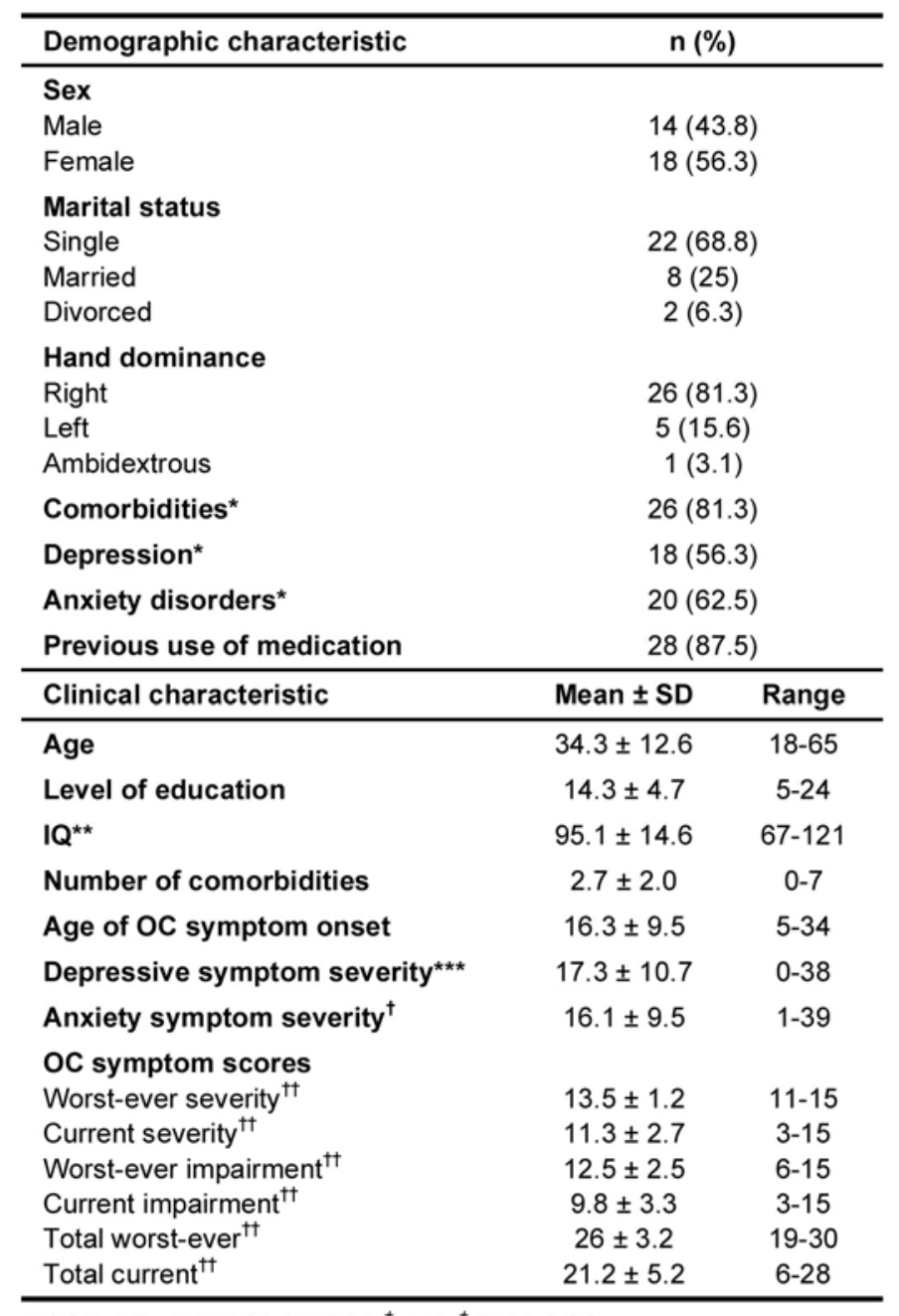

* SCID-I/P; ** WASI; *** BDI; ${ }^{\dagger} B A I ;{ }^{\dagger} D Y-B O C S$.

Global total scores on the DY-BOCS and Y-BOCS scores were highly correlated $(\mathrm{r}=0.8, \mathrm{p}<0.0001)$. Total DY-BOCS worst-ever severity scores correlated significantly with the planning score on the copy portion of the ROCFT $(r=0.4, p=0.04) .{ }^{17,19,20}$
Table 3 - Strategic planning scores in 32 patients with OCD

\begin{tabular}{lcc}
\hline \multicolumn{1}{c}{ Variable } & Mean \pm SD & Range \\
\hline Planning score on the copy portion & $5.3 \pm 1.3$ & $1-6$ \\
$\begin{array}{l}\text { Planning score on the immediate recall } \\
\text { portion }\end{array}$ & $4.1 \pm 1.9$ & $0-6$ \\
\hline
\end{tabular}

${ }^{*}$ Rey-Osterrieth Complex Figure Test

In the linear regression, only the total DY-BOCS worst-ever scores were found to be significantly associated with the planning score on the copy portion of the ROCFT $(\beta=0.55, t=2.1$, $\mathrm{p}=0.04)$.

Using Pearson's correlation coefficient to compare the planning score on the copy portion of the ROCFT with the OC symptom dimension scores (Table 4), we found a significant correlation only for the DY-BOCS worst-ever score for the hoarding dimension $(r=0.5, p=0.01)$. Even after being adjusted for age, level of education, depression, and IQ, this correlation retained its statistical significance $(\mathrm{r}=0.4, \mathrm{p}=0.03)$. The aggression dimension was also associated with the planning score on the copy portion of the ROCFT, although the correlation was not significant $(\mathrm{r}=0.4, \mathrm{p}=0.1)$.

\section{Discussion}

This is the first study to investigate the association between strategic planning and OC symptom dimensions. Our results underscore the idea that OCD is a heterogeneous disorder, and that different $\mathrm{OC}$ symptom dimensions have specific clinical and neuropsychological correlates.

Our findings demonstrate that, in patients with OCD, the peak severity of the symptoms, especially that of hoarding, is associated with strategic planning. Hoarding is quite common in OCD. Studies indicate that $15-40 \%$ of OCD patients have hoarding. ${ }^{34}$ In the present study, $62.5 \%$ of the patients evaluated reported current hoarding and $68.8 \%{ }^{34}$ provided a worst-ever score for hoarding. The presence of hoarding in OCD has been associated with the following: a greater number of axis I or II comorbidities; limitations of activities of daily living; poor insight; poor response

Table 2 - Worst-ever and current severity of OC symptoms, by dimension

\begin{tabular}{lccc}
\hline OC symptom dimension & Severity & Mean \pm SD & Range \\
\hline Aggressive obsessions \& compulsions & Worst-ever & $7.7 \pm 5.6$ & $0-14$ \\
& Current & $5.6 \pm 5.0$ & $0-14$ \\
Sexual/religious obsessions \& compulsions & Worst-ever & $5.9 \pm 5.5$ & $0-14$ \\
& Current & $4.2 \pm 4.7$ & $0-14$ \\
Symmetry obsessions \&compulsions & Worst-ever & $9.7 \pm 4.1$ & $0-15$ \\
& Current & $7.2 \pm 4.1$ & $0-13$ \\
Contamination obsessions \& cleaning compulsions & Worst-ever & $9.4 \pm 5.3$ & $0-15$ \\
& Current & $6.5 \pm 4.3$ & $0-14$ \\
Hoarding obsessions \& compulsions & Worst-ever & $6.7 \pm 5.3$ & $0-15$ \\
& Current & $4.8 \pm 4.3$ & $0-13$ \\
Miscellaneous obsessions \& compulsions & Worst-ever & $7.9 \pm 4.5$ & $0.4 \pm 4.5$ \\
\hline
\end{tabular}

${ }^{\star} D Y-B O C S$ 
Table 4 - Correlations between the planning score on the copy portion of the ROCFT and OC symptom severity, by dimension*

\begin{tabular}{|c|c|c|}
\hline OC symptom dimension & Severity & Planning score \\
\hline \multirow[t]{2}{*}{ Aggressive obsessions \& compulsions } & Worst-ever & 0.4 \\
\hline & Current & 0.2 \\
\hline \multirow[t]{2}{*}{ Sexual/religious obsessions \& compulsions } & Worst-ever & -0.1 \\
\hline & Current & -0.3 \\
\hline \multirow[t]{2}{*}{ Symmetry obsessions \&compulsions } & Worst-ever & 0.3 \\
\hline & Current & 0.02 \\
\hline \multirow[t]{2}{*}{ Contamination obsessions \& cleaning compulsions } & Worst-ever & -0.05 \\
\hline & Current & -0.2 \\
\hline \multirow[t]{2}{*}{ Hoarding obsessions \& compulsions } & Worst-ever & $0.4^{\star \star}$ \\
\hline & Current & 0.3 \\
\hline \multirow[t]{2}{*}{ Miscellaneous obsessions \& compulsions } & Worst-ever & -0.2 \\
\hline & Current & -0.3 \\
\hline
\end{tabular}

${ }^{*}$ Adjusted for age, level of education, IQ, and a diagnosis of depression.

$* *<0.05$

to psychological and pharmacological treatment; and distinct genetic mechanisms. This suggests that hoarding is etiologically distinct or even represents a new syndrome, as some researchers have proposed. ${ }^{34}$

Within the cognitive-behavioral model, ${ }^{35}$ individuals with hoarding have problems in processing information in the areas of attention, categorization, memory, and decision-making. In individuals with compulsive hoarding, these dysfunctions can lead to deficits in executive functions, including strategic planning, and such deficits can, in turn, limit the ability of these individuals to organize their belongings and dispose of objects that are unused or useless. Our finding of a positive correlation between hoarding scores and strategic planning scores contradict those of some previous studies, in which deficits in strategic planning were reported in patients with hoarding compulsions. ${ }^{6,36}$ However, Simpson et al. found no significant differences between subjects with hoarding and healthy controls in terms of neuropsychological symptoms, including executive function. ${ }^{37}$ The present study presents certain differences in relation to previous studies: the mean planning score on the copy portion of the $\mathrm{ROCFT}^{6}$ was higher in our study than in others; ${ }^{3,4}$ and, unlike the authors of some other studies, ${ }^{4}$ we considered hoarding a dimensional variable.

Our study has certain limitations, because it was an exploratory study, with a small number of subjects and without a control group. Nevertheless, our data show that the strategic planning score on the copy portion of the ROCFT correlated with OC symptom dimensions, and that this correlation is probably attributable to an association with the hoarding dimension. These results underscore the idea that OCD is a heterogeneous disorder, as well as highlighting the importance of assessing specific symptom dimensions.

\section{Acknowledgements}

This study received financial support from the Consórcio Brasileiro de Pesquisa em Transtornos do Espectro Obsessivo-Compulsivo (CTOC,
Brazilian Research Consortium on Obsessive-Compulsive Spectrum Disorders). We are also grateful for the cooperation of the participating OCD patients and their family members. 


\section{Disclosures}

\begin{tabular}{|c|c|c|c|c|c|c|c|}
\hline $\begin{array}{l}\text { Writing group } \\
\text { member }\end{array}$ & Employment & $\begin{array}{c}\text { Research } \\
\text { grant }^{1}\end{array}$ & $\begin{array}{l}\text { Other research grant } \\
\text { or medical continuous } \\
\text { education }\end{array}$ & $\begin{array}{l}\text { Speaker's } \\
\text { honoraria }\end{array}$ & $\begin{array}{c}\text { Ownership } \\
\text { interest }\end{array}$ & $\begin{array}{l}\text { Consultant/ } \\
\text { Advisory } \\
\text { board }\end{array}$ & Other ${ }^{3}$ \\
\hline $\begin{array}{l}\text { Paula Sanders } \\
\text { Pereira Pinto }\end{array}$ & $\begin{array}{l}\text { UNIFACS } \\
\text { UFBA }\end{array}$ & СТОС & - & - & - & - & - \\
\hline Sandro lego & UFBA & СTOC & - & AstraZeneca & - & - & - \\
\hline $\begin{array}{l}\text { Samantha } \\
\text { Nunes }\end{array}$ & UFBA & СТOC & - & - & - & - & - \\
\hline $\begin{array}{l}\text { Hemanny } \\
\text { Menezes }\end{array}$ & UFBA & СТOC & - & - & - & - & - \\
\hline $\begin{array}{l}\text { Rosana Sávio } \\
\text { Mastrorosa }\end{array}$ & UNIFESP & СТOC & - & - & - & - & - \\
\hline $\begin{array}{l}\text { Irismar Reis de } \\
\text { Oliveira }\end{array}$ & $\begin{array}{l}\text { UNIFESP } \\
\text { UFBA }\end{array}$ & СТОС & $\mathrm{CNPq}^{\star * \star}$ & $\begin{array}{l}\text { Novartis* } \\
\text { Janssen* }\end{array}$ & - & - & - \\
\hline
\end{tabular}

\section{* Modest}

** Significant

*** Significant: Amounts given to the author's institution or to a colleague for research in which the author has participation, not directly to the author.

Note: UNIFACS = Universidade de Salvador; UFBA = Universidade Federal da Bahia; UNIFESP = Universidade Federal de São Paulo; CTOC = Consórcio Brasileiro de Pesquisa em Transtorno Obsessivo-Compulsivo; CNPq= Conselho Nacional de Desenvolvimento Científico e Tecnológico.

For more information, see Instructions for Authors

\section{References}

1. DSM-IV-TR. Manual diagnóstico e estatístico de transtornos mentais. 4 ed. Porto Alegre: Artmed; 2002.

2. Fontenelle L. Aspectos neuropsicológicos do transtorno obsessivo-compulsivo. Rev Bras Psiquiatr. 2001;23(Suppl II):27-30.

3. Penadés R, Catalán R, Andrés S, Salamero M, Gastó C. Executive function and nonverbal memory in obsessive-compulsive disorder. Psychiatry Res. 2005;133(1):81-90.

4. Savage CR, Baer L, Keuthen NJ, Brown HD, Rauch SL, Jenike MA. Organizational strategies mediate nonverbal memory impairment in obsessive-compulsive disorder. Biol Psychiatry. 1999;45(7):905-16.

5. Mataix-Cols D, Alonso P, Hernandez R, Deckersbach T, Savage CR, Manuel Menchon J, Vallejo J. Relation of neurological soft signs to nonverbal memory performance in obsessive-compulsive disorder. J Clin Exp Neuropsychol. 2003;25(6):842-51.

6. Oliveira MS. Figuras de Rey: Teste de cópia e de reprodução de memória de figuras geométricas complexas. Manual André Rey. Rey T, Franco LC [trad.]. São Paulo: Casa do Psicólogo; 1999.

7. Savage CR, Deckersbach T, Wilheim S, Rauch SL, Baer L, Reid T, Jenike MA. Strategic processing and episodic memory impairment in obsessivecompulsive disorder. Neuropsychology. 2001;14(1):141-51.

8. Choi JS, Kang DH, Kim JJ, Ha TH, Lee JM, Youn T, Kim IY, Kim SI, Kwon JS. Left anterior subregion of orbitofrontal cortex volume reduction and impaired organizational stratigies in obsessive-compulsive disorder. J Psychiatr Res. 2004;38(2):193-9.

9. Miguel EC, Leckman JF, Rauch S, Rosario-Campos MC, Hounie AG, Mercadante MT, Chacon P, Pauls D. Obsessive-compulsive disorder phenotypes: implications for genetic studies. Mol Psychiatry. 2005;(10):258-75.

10. Geller D, Biederman J, Jones J, Park K, Schwartz S, Shapiro S, Coffey B. Is juvenile obsessive-compulsive disorder a developmental subtype of the disorder? A review of the pediatric literature. J Am Acad Child Adolesc Psychiatry. 1998;37(4):420-7.

11. Rosario-Campos MC, Leckman JF, Mercadante MT, Shavitt RG, Prado HS, Zamignani D, Miguel EC. Adults with early-onset obsessive-compulsive disorder. Am J Psychiatry. 2001;158(11):1899-903.

12. Miguel EC, do Rosário-Campos MC, Prado HS, do Valle R, Rauch SL, Coffey BJ, Baer L, Savage CR, O’Sullivan RL, Jenike MA, Leckman JF. Sensory phenomena in obsessive-compulsive disorder and Tourette's disorder. $J$ Clin Psychiatry. 2000;61(2):150-7.

13. Leckman JF, Grice DE, Boardman J, Zhang H, Vitale A, Bondi C, Alsobrook J, Peterson BS, Cohen DJ, Rasmussen SA, Goodman WK, Mcdougle CJ, Pauls DL. Symtoms of obsessive-compulsive disorder. Am J Psychiatry. 1997;154(7):911-7.

14. Mataix-Cols D, Rosário-Campos MC, Leckman JF. A multidimensional model of obsessive-compulsive disorder. Am J Psychiatry. 2005;162(2):228-38.

15. Bloch MH, Landeros-Weisenberger A, Rosario MC, Pittenger C, Leckman JF. Meta-analysis of the symptom structure of obsessive-compulsive disorder. Am J Psychiatry. 2008;165(12):1532-42.

16. Mataix-Cols D, Rauch SL, Baer L, Eisen JL, Shera DM, Goodman WK, Rasmussen SA, Jenike MA. Symptom stability in adult obsessive compulsive disorder: data from a naturalistic two-year follow-up study. Am J Psychiatry. 2002;159(2):263-8.

17. Rufer M, Grothusen A, Mass R, Peter H, Hand I. Temporal stability of symptom dimensions in adult patients with obsessive-compulsive disorder. J Affect Disord. 2005;88(1):99-102.

18. Delorme R, Bille A, Betancur C, Mathieu F, Chabane N, Mouren-Simeoni MC, Leboyer M. Exploratory analysis of obsessive compulsive symptom dimensions in children and adolescents: a prospective follow-up study. BMC Psychiatry. 2006;6:1.

19. McKay D, Piacentini J, Greisberg S, Graae F, Jaffer M, Miller J. The structure of childhood obsessions and compulsions: dimensions in an outpatient sample. Behav Res Ther. 2006;44(1):137-46.

20. Mataix-Cols D, Rahman Q, Spiller M, Alonso MP, Pifarré J, Menchón JM, Vallejo J. Are there sex differences in neuropsychological functions among patients with obsessive-compulsive disorder? Appl Neuropsychol. 2006;13(1):42-50.

21. Mataix-Cols D, Rauch SL, Manzo PA, Jenike MA, Baer L. Use of FactorAnalyzed Symptom Dimensions to Predict Outcome With Serotonin Reuptake Inhibitors and Placebo in the Treatment of ObsessiveCompulsive Disorder. Am J Psychiatry. 1999;156(9):1409-16.

22. Erzegovesi S, Cavallini MC, Cavedini P, Diaferia G, Locatelli M, Bellodi L. Clinical predictors of drug response in obsessive-compulsive disorder. $J$ Clin Psychopharmacol. 2001;21(5):488-92.

23. Saxena S, Maidment KM, Vapnik T, Golden G, Rishwain T, Rosen RM, Tarlow G, Bystritsky A. Obsessive-compulsive hoarding: symptom 
severity and response to multimodal treatment. J Clin Psychiatry. 2002;63(1):21-7.

24. Miguel EC, Ferrão YA, Rosário MC, Mathis MA, Torres AR, Fontenelle LF, Hounie AG, Shavitt RG, Cordioli AV, Gonzalez CH, Petribú K, Diniz JB, Malavazzi DM, Torresan RC, Raffin AL, Meyer E, Braga DT, Borcato S, Valério C, Gropo LN, Prado Hda S, Perin EA, Santos SI, Copque H, Borges MC, Lopes AP, Silva ED. The Brazilian Research Consortium on Obsessive-Compulsive Spectrum Disorders: recruitment, assessment instruments, methods for the development of multicenter collaborative studies and preliminary results. Rev Bras Psiquiatr. 2008;30(3):185-96.

25. First MB, Spitzer RL, Williams JBW, Gibbon M. Structured clinical interview for DSM-IV axis I disorders-patient edition. SCID-I/P, Version 2.0. New York, Biometric Research Departamen: New York State Psychiatric Institute; 1995.

26. Rosário-Campos MC, Miguel EC, Quatrano S, Chacon P, Ferrao Y, Findley D, Katsovich L, Scahill L, King RA, Woody SR, Tolin D, Hollander E, Kano Y, Leckman JF. The Dimensional Yale-Brown Obsessive-Compulsive Scale (DY-BOCS): an instrument for assessing obsessive-compulsive symptom dimensions. Mol Psychiatry. 2006;11(5):495-504.

27. Goodman WK, Price LH, Rasmussen SA, Mazure C, Fleischmann RL, Hill CL, Heninger GR, Charney DS. The Yale-Brown Obsessive Compulsive Scale: I. Development, use and reliability. Arch Gen Psychiatry. 1989;46(11):1006-11.

28. Beck AT, Ward CH, Mendelsohn M, Mock J, Erbaugh J. An inventory for measuring depression. Arch Gen Psychiatry. 1961;4:561-71.

29. Gorenstein CE, Andrade L. Validation of a Portuguese version of the Beck Depression Inventory and the State-Trait Anxiety Inventory in Brazilian subjects. Braz J Med Biol Res. 1996;29(4):453-57.

30. Beck AT, Epstein N,Brown G, Steer RA. An inventory for measuring clinical anxiety: psychometric properties. J Consult Clin Psychol. 1988;56(6):89397.

31. Wechsler D. WASI: Escala de Inteligência Wechsler abreviada. São Paulo: Casa do Psicólogo; 2005.

32. Oliveira M, et al. Validação do Teste Figuras Complexas de Rey na População Brasileira. Aval Psicol. 2004;3(1):33-8.

33. Norussis MJ. Statistical Package for Social Science (SPSS) for windows advanced statistics release 15.0. Chicago, USA: SPSS Inc.; 2006.

34. Pertusa A, Fullana MA, Singh S, Alonso P, Menchón JM, Mataix-Cols D. Compulsive hoardings: OCD symptom, distinct clinical syndrome, or both? Am J Psychiatry. 2008;165(10):1289-98.

35. Frost RO, Hartl T. A cognitive-behaviour model of compulsive hoarding. Behav Res Ther. 1996;34(4):341-50.

36. Wincze JP, Steketee G, Frost RO. Categorization in compulsive hoarding. Behav Res Ther. 2007;45(1):63-72.

37. Simpson HB, Rosen W, Huppert JD, Lin SH, Foa EB, Liebowitz MR. Are there reliable neuropsychological deficits in obsessive-compulsive disorder? J Psychiatr Res. 2006;40(3):247-57. 